\title{
Government Roles in the Industrial Generic Technology Innovation Research
}

\author{
Wei Chunyan \\ School of Marxism, Northeastern University \\ Shenyang, China \\ weichunyan323@126.com
}

\author{
Li Zhaoyou \\ School of Humanities and Law, Northeastern University, \\ Shenyang, China \\ lizhaoyou@wfxy.neu.edu.cn
}

\begin{abstract}
To eliminate "the double failure" in the process of industrial generic technology innovation obstacles, the government needs to play a role in the innovation process. This paper adopts the view of technology process theory, taking the stage of innovation decision-making, the stage of innovation and development, and the stage of innovation and diffusion as the clue in the process of industrial generic technology innovation, aiming at addressing different stages in the process of industrial generic technology innovation on government function innovation dilemma. According to the different stages of the innovation process, the role of government in industrial generic technology innovation is concerned with the scope of the intervention, methods and specific function. To be timely and modest, government should guarantee the industrial generic technology innovation smoothly.
\end{abstract}

Keywords-Industrial generic technology innovation; the view of technology process theory; "The double failure"; The government role

\section{INTRODUCTION}

According to Chinese famous philosopher of technologyDeyu Yuan, technology is a dynamic evolution process. From the perspective of technology process theory, the technology can be divided into laboratory technology, generic technology, application technology and proprietary technology [1]. Similarly, G. Tassey studied the different composition of technology by use of the economics method and made a similar division of technology, namely, basic technology, generic technology and proprietary technology. Generic technology is the first step in bringing the scientific knowledge obtained from the basic research stage to the market. It is in essence of the concept of validation. It is the foundation of the subsequent application and development, which belongs to the part of technological infrastructure [2]. It is generally believed in China that industrial generic technology plays an important role in the industrial level of technology, production efficiency and industrial quality, etc, which are seen as a class of social and economic benefits of technology applied in many areas. The outcomes of this class of technology can have a deeper influence on the whole industry [3].Industrial generic technology and common technology on these two concepts in the study does not differentiate between industrial generic technology and generic technology. This term 'Generic technology' is generally used in an international context whereas the term "industrial generic technology" is often

Fund Project: General Project of National Social Science Foundation of China (16BZX028), entitled by " Marx 's Technology and Modernity Criticism and Its Contemporary Value"

Author: Wei Chunyan. PhD Candidate; Philosophy of science and technology; School of Marxism; Northeastern University; research direction: Technological innovation; Date of birth: 1983.3; E-mail: weichunyan323@126.com; Tel: 13704829740

LI Zhaoyou. PhD Tutor; professor; School of Humanities and Law;

Northeastern University; research direction: technological innovation, science and technology policy; Date of birth: 1965.5; E-

mail:lizhaoyou@wfxy.neu.edu.cn.

Copyright (C) 2017, the Authors. Published by Atlantis Press. referred in the related Chinese literature. Regardless of the appellation, there is no unified definition currently in an international context but the generic technology plays a fundamental role in the evolution of the whole technology process to meet the needs of multiple industries. On this basis, it has carried out the second innovative program, providing a platform for meeting proprietary marketing needs of numerous users. It provides supports for the technological progress and development of relevant industries, which have reached consensus. Therefore, the industrial generic technology innovation is seen as the basis of technological innovation, the upgrading of the industry support and the engine of economic development.

The properties of "quasi-public product" and the characteristics (e.g. externality, relevance, sharing, and risk) of industrial generic technology have brought about two big obstacles, namely, market failure and organizational failure in industrial generic technology innovation. Therefore, the government needs to solve the problem of "double failure". Industrial generic technology innovation is a dynamic process, so this paper chooses the view of technology process theory, divides the process of industrial generic technology into the following stages: the stage of innovation decision-making, the stage of innovation and development, and the stage of innovation and diffusion. This paper takes the process of industrial generic technological innovation as a clue, aiming at addressing the government role in dealing with different stages of innovation dilemma for the industrial generic technology innovation process.

\section{THE POLICY BASIS OF GOVERNMENT 'S INTERVENTION IN THE GENERIC TECHNOLOGY INNOVATION OF INDUSTRY}

\section{A. "Market failure" of industrial generic technology innovation}

Public product attributes of industrial generic technology indicate that it has strong externality. Due to externalities, it is difficult to define the property right of industrial generic technology. The industrial generic technology innovation enterprises for $R \& D$ cannot monopolize industrial generic technology innovation and all the benefits[4]; Combined with time lag of the industrial generic technology investment risks and benefits, G. Tassey argued that the additional market risk of generic technology $R \& D$ will lead to the combination of high risk and high discount rates. The result of corporate 
rational decision must be reflected in "underinvestment" for generic technology [5].

From the perspective of transaction cost theory, transaction cost of industrial generic technology includes the technology of learning cost and the cumulative cost, etc. The transaction cost is quite high, which causes industrial generic technology market to have trade barriers [4]87. Accordingly, a single enterprise lacks the power of industrial generic technology innovation, finally leading to "market failure" of industrial generic technology innovation. The "market failure" of industrial generic technology innovation provides the theoretical basis for the government to intervene in the industrial generic technology innovation.

\section{B. "Organizational failure" of inndustrial generic technology innovation}

There are organizational failures in the process of R\&D of industrial generic technology innovation and the diffusion. Due to the risk of industrial generic technology innovation, the single individual cannot bear the high risk in the process of innovation, and their ability and resources cannot meet the demand of $\mathrm{R} \& \mathrm{D}$ [6]. Even if a single individual has succeeded in research and development, it is difficult to complete the diffusion of innovation, to achieve low cost and to optimize the allocation of social resources. The relevance of industrial generic technology determines its innovative R \& D which requires a number of actors in research and development cooperation, but the industrial generic technology innovation cooperation also exist organizational failure. Industrial generic technology innovation cooperation involves innovation risk sharing, innovation of benefit sharing and so on, leading to low power of a single individual cooperation between research and development. Even after the success of the cooperative R\&D, the property right problem and high cost of diffusion cannot realize effective diffusion of innovative research and development, so a single individual is difficult to finish the task of industrial generic technology innovation cooperation. Hereby, government should take its role of intervention in providing an organizational platform for $R \& D$ of industrial generic technology innovation cooperation.

The "double failures" in industrial generic technology innovation provide the theoretical basis for government's intervention in the process of industrial generic technology innovation, but how can government dispel the "dual failures" in the innovation process? Furthermore, how can government play a role in the industrial generic technology innovation? That is, the questions are involved in the scope, methods, extent, etc., for the role of government in industrial generic technology innovation. This paper will give an account of clear and complete logic analysis in light of the three stages of industrial generic technology innovation, based on the process of industrial generic technology innovation.

\section{THE ROLE OF GOVERNMENT IN INDUSTRIAL GENERIC TECHNOLOGY INNOVATION}

From the view of technology process theory, the innovation dilemma at different stages in the process of industrial generic technology innovation provides us with a horizontal research clues from government intervention: Industrial generic technology innovation decision-making stage-Industrial generic technology innovation research and development stageIndustrial generic technology innovation diffusion stage. The "scope of action-function of action -mode of action-degree of action" from government constitutes a longitudinal research clue of specific government role in industrial generic technology innovation. It also provides a guiding framework for this paper to use the cross-clues from Vertical and horizontal dimensions to resolve the problem of the "double failures" in the interaction of industrial generic technology innovation, so as to guarantee the smooth progress of the industrial generic technology innovation, as shown in table 1.

\section{A. The role of government in industrial generic technology innovation decision-making}

Industrial generic technology innovation decision-making stage is the preliminary stage of the research and development of industrial generic technology innovation, which is viewed as the starting point of the evolution of industrial generic technology. The plight of this stage is that the enterprise as the main actor of industrial generic technology innovation will have difficulty in making innovative decisions, because the market currently is not perfectly competitive, causing asymmetry phenomenon of relevant industrial generic technology information. In the practice of the industrial generic technology innovation, this asymmetric information leads to market failure from the innovation resources allocation. Moreover, the basic and delay characteristics of industrial generic technology make the application prospect of industrial generic technology innovation achievements difficult to realize immediately. Meanwhile, there is uncertainty for a huge investment income, which is unable to recover the cost of investment risk at any time. Enterprises hereby get into decision dilemma and they give up R\&D of industrial generic technology innovation.

To solve the problem of decision-making of industrial generic technology innovation, the government role in industrial generic technology innovation decision-making phase is: First, to provide a judgment basis for industrial generic technology innovation. In view of the demand information asymmetry of industrial generic technology innovation in the market environment, by use of professional technology sector guidance and planning advantages of information sorting, the government can rely on a large number of the public data statistics and processing capacity to issue a clear common technological demand information and future demand direction to the enterprises, in order to reduce the risks of the information asymmetry to the enterprise and to increase the enthusiasm of enterprise innovation. The second is to reduce the risk of industrial common technology innovation decision - making. The government needs to help enterprises identify industrial generic technology, that is, to judge what kinds of industrial requirements the innovation of industrial generic technology can meet. The government should organize a large number of scientific research and international technical exchanges and cooperation, in order to establish the key generic technology of strategic dominance at different stages of industrial development, and formulate detailed development programs for industrial generic technology innovation, according to the development path of different industrial 
generic technology and the systematic relations among various technologies. On the other hand, the government should strengthen the guiding role of industrial policy, and guide enterprises to focus on $R \& D$ of different industries and industries in terms of major generic technology.

TABLE I. THE GOVERNMENT'S ROLE IN THE INDUSTRIAL GENERIC TECHNOLOGY INNOVATION RESEARCH FRAMEWORK

\begin{tabular}{|c|c|c|c|}
\hline $\begin{array}{l}\text { Longitudinal } \\
\text { Research Clues }\end{array}$ & $\begin{array}{l}\text { Innovation Of Decision- } \\
\text { making Stage }\end{array}$ & Innovation Development Stage & Innovation Diffusion Stage \\
\hline $\begin{array}{l}\text { The role of government in } \\
\text { scope }\end{array}$ & $\begin{array}{l}\text { Industrial generic technology } \\
\text { innovation information } \\
\text { asymmetry, torn decision } \\
\text { because of the investment } \\
\text { risks and benefits of risk }\end{array}$ & $\begin{array}{l}\text { A single actor in } \mathrm{R} \& \mathrm{D} \text { is } \\
\text { unable to do the job; a single } \mathrm{R} \\
\& \mathrm{D} \text { development has } \\
\text { difficulties in cooperation }\end{array}$ & $\begin{array}{l}\text { Diffusion parties are reluctant to } \\
\text { promote the industrial } \\
\text { technological innovation; the } \\
\text { recipient is unable to accept the } \\
\text { innovation results; the results of } \\
\text { the innovation is underestimated }\end{array}$ \\
\hline $\begin{array}{c}\text { The role of government in } \\
\text { function }\end{array}$ & $\begin{array}{l}\text { Provide a basis for industrial } \\
\text { generic technology } \\
\text { innovation decision } \\
\text { judgment; Reduce the risk of } \\
\text { industrial generic technology } \\
\text { innovation decision-making }\end{array}$ & $\begin{array}{l}\text { Reduce the risk of research and } \\
\text { development of industrial } \\
\text { generic technology innovation; } \\
\text { To promote research and } \\
\text { development of industrial } \\
\text { generic technology innovation } \\
\text { cooperation }\end{array}$ & $\begin{array}{l}\text { To promote industrial generic } \\
\text { technology innovation } \\
\text { diffusion; Industrial generic } \\
\text { technology innovation diffusion } \\
\text { of "market failure"; Establish } \\
\text { information feedback } \\
\text { mechanism, ensure the } \\
\text { innovation cycle }\end{array}$ \\
\hline $\begin{array}{c}\text { The role of government in } \\
\text { methods }\end{array}$ & $\begin{array}{l}\text { Explicitly release generic } \\
\text { technology demand } \\
\text { information; To identify the } \\
\text { generic technology; Policy } \\
\text { guidance }\end{array}$ & $\begin{array}{l}\text { Different research entities, the } \\
\text { strength of the different types of } \\
\text { generic technology take other } \\
\text { financial support; Strengthen } \\
\text { the generic technology project } \\
\text { management, form risk-sharing; } \\
\text { A good macro environment for } \\
\text { innovation; Effective } \\
\text { organization cooperation } \\
\text { innovation, form innovation } \\
\text { coalition, clear relationship in } \\
\text { liability; Develop talent training } \\
\text { and security system }\end{array}$ & $\begin{array}{l}\text { Different types of generic } \\
\text { technology innovation } \\
\text { achievements of subsidies } \\
\text { policy; Diffusion and receiver } \\
\text { to reduce risk support } \\
\text { respectively; Establish a } \\
\text { common technological } \\
\text { achievements evaluation } \\
\text { system; Establishing } \\
\text { intermediary service system and } \\
\text { innovation service platform; } \\
\text { Establish feedback mechanism, } \\
\text { preparing for continuous } \\
\text { innovation }\end{array}$ \\
\hline $\begin{array}{c}\text { The role of government in } \\
\text { extent }\end{array}$ & $\begin{array}{l}\text { Explicitly release generic } \\
\text { technology demand } \\
\text { information; To identify the } \\
\text { generic technology; Policy } \\
\text { guidance }\end{array}$ & $\begin{array}{l}\text { Different research main body, } \\
\text { the strength of the different } \\
\text { types of generic technology take } \\
\text { other financial support; } \\
\text { Strengthen the generic } \\
\text { technology project } \\
\text { management, form risk-sharing; } \\
\text { A good macro environment for } \\
\text { innovation; Effective } \\
\text { organization cooperation } \\
\text { innovation, form innovation } \\
\text { coalition, clear relationship in } \\
\text { liability; Develop talent training } \\
\text { and security system }\end{array}$ & $\begin{array}{l}\text { Different types of generic } \\
\text { technology innovation } \\
\text { achievements of subsidies } \\
\text { policy; Diffusion and receiver } \\
\text { to reduce risk support } \\
\text { respectively; Establish a } \\
\text { common technological } \\
\text { achievements evaluation } \\
\text { system; Establishing } \\
\text { intermediary service system and } \\
\text { innovation service platform; } \\
\text { Establish feedback mechanism, } \\
\text { preparing for continuous } \\
\text { innovation }\end{array}$ \\
\hline
\end{tabular}

\section{B. The role of government in industrial generic technology} innovation research and development

The development stage of the generic technology innovation is a complex process that the actor that puts the innovative resources organized and applied into the research and development of innovation and makes it transformed into the industrial generic technology innovation, which can meet the social demand. It is the key point in the process of industrial generic technology innovation. This stage is facing difficulties: First, a single R \& D lacks technical personnel, and has high innovation risks, high costs of innovation and inability to carry out industrial generic technology innovation and development. Second, the characteristics of the generic technology of the industry decides R \& D of innovation that requires a number of actors in cooperation, but in the practice of innovation, it is difficult to complete the cooperation task of generic technology innovation of the industry due to the cooperation innovation cost and the technical monopoly barrier.

To solve the problem of $\mathrm{R} \& \mathrm{D}$ of industrial generic technology innovation, the government's role in industrial generic technology innovation research and development phase is: First, to reduce the risk of research and development of industrial generic technology innovation. For one thing, to provide the financial support for industrial generic technology research and development. At this stage, government's "effective ways for financial aid will be tax preferences, free 
subsidies and investment subsidies" [7]. The government specifically select the funding targets of industrial generic technology innovation and have different levels of support toward different actors for R\&D; And according to the different types of industrial generic technology, it takes the fiscal and taxation and financing support, government procurement, with selective support measures such as generic technology research and development of for-profit institutions[8]. For another, for the management of government it strengthens the generic technology project selection and project process management and performance evaluation method; Funding of research and development of industrial generic technology innovation of scientific is under a standardized management, so as to improve the use efficiency of scientific research; to strengthen the management of the venture capital market. Through risk investment mechanism, the actors of research and development share various risks in the process of common technology research and development, so as to reduce the uncertainty in the process of common technology research and development. The second is to promote the common development of production and research cooperation. For one thing, through the guidance of planning, institutional guarantee, perfecting the laws and regulations, etc. the government eliminates technological monopoly barriers, creating innovation climate, guiding the innovation actors' active voluntary cooperation. For another, industrial generic technology innovation cooperation in research and development is effectively organized. The government guides the establishment of Industry-University-Research Institute Alliance, gives all power to enterprises, universities and research institutions by the integration of resources of science and technology to realize the complementary advantages; According to the requirements of industrial generic technology innovation, government can coordinate the development relations between the rights, responsibilities and interests of the principal ,and can clear of property rights of industrial generic technology research and development and sharing mechanism. It prevents the disadvantages of generic technology research and development system of organization. Third, pay attention to industrial generic technology innovation talents training. The government provides system support for personnel training and development mechanism, personnel service guarantee mechanism and talent reward mechanism. Moreover, Innovative salary distribution system and the supporting talent policy are made to protect the industry to promote generic technology innovation and development of talent supply.

\section{The role of government in industrial generic technology innovation diffusion}

During industrial generic technology innovation diffusion phase, it has completed the industrial generic technology innovation and the products of innovation have been put into the market. The innovation entities have obtain industrial generic technology innovation income, and other enterprises have continued to do the second innovative program on the basis of the results of industrial generic technology innovation. The difficulties of this stage are: firstly, the diffusion party has difficulty in the promotion of industrial generic technology innovation achievement. For one thing, due to profit-driven, the diffusion entities will not take the initiative to share industrial generic technology innovation achievement with the society, unless they meet the demand of their interests. For another, "quasi-public product" attribute and externality of industrial generic technology benefit the receiver in the research and development of industrial generic technology innovation achievements, but they do not pay the cost, the diffusion entities did not get the proper remuneration. In the diffusion process, the economic interests and enthusiasm of innovation are damaged, and the subsequent supply of $R \& D$ industrial generic technology will be reduced, if not effective diffusion, social and economic value of industrial generic technology innovation cannot be bound, which will lead to industrial generic technology without continuous innovation. Secondly, after the completion of the industrial generic technology innovation, it needs to have second development to form the enterprise proprietary technology, so the generic technology innovation that just has been finished is usually undervalued by the receivers, and they are unwilling to accept this kind of technology; Or receivers due to the lack of corresponding technical ability, can not complete after secondary development, leading to technical inefficiency of market transactions, generic technology innovation diffusion caused by "market failure".

To solve the problem of industrial generic technology innovation diffusion, the government's role in industrial generic technology innovation diffusion phase is: First, to promote the industrial generic technology innovation diffusion. Different levels of subsidy policies are made towards different types of generic technology innovation; Tax preferential policies are made to protect the interests of the parties and the recipient of the legitimate interests of the results of the transaction; Technical and economic policies are made to promote the proliferation; The intellectual property policies are made to protect the proliferation of industrial generic technology innovation results and its exclusiveness; Innovative outcomes diffusion and cooperation risk prevention guidance policy are made to reduce the risk of proliferation. The second is to eliminate of industrial generic technology innovation diffusion of "market failure". For one thing, to establish a common technical achievements evaluation system. Guiding generic technology value evaluation method reduces the information asymmetry of generic technology diffusion and earnings uncertainty. For another, the platform is built as it is conducive to the spread of the intermediary service system and innovation service. With the specialized intermediary organizations, the information resources, diversification of marketing channels, etc.[9], establishing intermediary service system, make the effective promotion of generic technology innovation diffusion party, the receiver general technology and get the required information in time; Government-led structures, generic technology innovation service platform, solve the receiver of generic technology innovation diffusion, due to insufficient resources and capital, less information channel, unwilling or unable to accept the plight of generic technology innovation, through the generic technology innovation service platform. The receiver can not only obtain industry competent departments for technical support, but also could get a faster, cheaper generic technology innovation. Third, the establishment of information feedback mechanism is made for ensuring the innovation cycle. Looking for the innovation process to promote or hinder the role of the dominant feedback 
loop, innovation of the node information feedback mechanism is done through the information feedback for restricting the development of generic technology innovation and timely grasp the key reason and the problems existing in the process of industrial generic technology innovation, which provides the basis for the constant industrial generic technology innovation.

\section{CONCLUSION}

Based on the view of technology process theory, this paper takes the process of industrial generic technology innovation as clues, addressing the role of government in facing the difficulty in the process of industrial generic technology innovation at different stages. The objective of this study is more targeted and effective based on the role of government in the stages of different process of technological innovation. This will make clear for understanding the role of government in the scope, methods and extent of industrial generic technology innovation. It provides a certain reference to the government for timely, appropriate intervention of the future industrial generic technology innovation

\section{REFERENCES}

[1] Xu Xin, Generic technology innovation in the process of government procurement policies embedded research [D]. Harbin industrial university, Ph.D. Dissertation, 2015 (3): 23.
[2] Tassey G. Competing in Advanced Manufacturing : The Need for Improved Growth Models and Policies [J] . Journal of Economic Perspectives, 2014, 28 (1) : 37-40.

[3] Li Jian-ling, Liu Yi, Mahindra. Generic technology alliance of interests distribution study [J]. Science and technology of China BBS, 2013 (7): 51-52.

[4] Li Guo-hao, Li Teng Teng. Based on the industrial generic technology innovation group game "market failure" study [J]. Journal of Shanghai economic studies, 2013 (11): 87.

[5] Tassey G. Beyond the business cycle: The need for a technologybased growth strategy $[\mathrm{J}]$. Science \& Public Policy, 2012, 40 (3) : 293-315.

[6] Ji Zhan Wu, Wang Qing. Industrial generic technology supply and the double failure -- -- in the United States SEMATECH, for example [J]. Science and technology and economy, 2012 (6): 11-12.

[7] Jiang Jian. China's industrial generic technology research and development and industrialization mode of government funding and management research $[\mathrm{J}]$. Science and technology management research, 2015 (17): 23

[8] Ding Ming Lei, Liu Bing Lian. Main problems and countermeasures of the construction of Chinese industrial technology system research [J]. Journal of scientific research management, 2012 (7): 33-39.

[9] SunLiang, LiJianLing, LiDaiSong. Industry technology innovation strategic alliance organization pattern and government function [J] Science and technology of China BBS, 2015 (3): 16. 